\title{
Oxytocin receptor gene expression in rat mammary gland: structural characterization and regulation
}

\section{Breton, D Di Scala-Guenot ${ }^{1}$ and $\mathbf{H}$ H Zingg}

Laboratory of Molecular Endocrinology, McGill University Health Centre, Montreal, Quebec H3A 1A1, Canada

${ }^{1}$ Institut de Physiologie, URA 1446, CNRS, Université Louis Pasteur, Strasbourg, France

(Requests for offprints should be addressed to H H Zingg, Laboratory of Molecular Endocrinology,

Royal Victoria Hospital, 687, Pine Ave West, Montreal, Quebec H3A 1A1, Canada;

Email: zingg@rvhri.lan.mcgill.ca)

(C Breton is now at Laboratoire d'Endocrinologie des Annélides, UPRESA CNRS 8017, SN3,

Université des Sciences et Technologies de Lille, 59655 Villeneuve d'Ascq, Cedex, France)

\begin{abstract}
The differential, tissue-specific regulation of oxytocin (OT) binding sites allows the neurohypophysial nonapeptide OT to fulfill a dual role: to induce uterine contractions at parturition and to mediate milk ejection during lactation. Whereas uterine OT binding sites are up-regulated prior to parturition and are rapidly down-regulated thereafter, mammary gland OT binding sites gradually increase throughout gestation and remain up-regulated during the ensuing lactation period. Here, we structurally characterized OT receptor (OTR) mRNA in mammary gland and analyzed its expression during gestation and lactation and in response to steroid treatment. In mammary gland tissues, we found a $6 \cdot 7$ and a $5 \cdot 4 \mathrm{~kb}$ OTR mRNA species, and both species were further analyzed by RACE (rapid amplification of cDNA ends). The $6.7 \mathrm{~kb}$ mRNA was found to be common to mammary gland and uterus and to extend 618 nucleotides beyond the published sequence of the rat OTR gene. The $5.4 \mathrm{~kb}$ mRNA species is unique to the mammary gland and terminates at a mammary gland-specific polyadenylation site that is not preceded by a classical polyadenylation signal. RT-PCR analysis did not provide any evidence for
\end{abstract}

differences in the coding regions, suggesting that both uterine and mammary gland OTR mRNAs encode the same receptor protein. Furthermore, primer extension experiments showed that no differences exist in the specific transcriptional initiation sites of the OTR gene in the two tissues. During pregnancy, OTR mRNA per mammary gland increased approximately 150 -fold and remained high during lactation, consistent with the previously identified regulation of OT binding sites and the role of OT during lactation. Whereas estrogen administration strongly induced the uterine OTR mRNA levels ( $>5$-fold), mammary gland remained unaffected by steroid treatment. Moreover, tamoxifen had no effect on the mammary gland OTR mRNA level. In summary, our data demonstrate a differential control of OTR expression in uterus versus mammary gland and a mammary gland-specific OTR mRNA polyadenylation site. However, this differential control apparently does not involve the expression of different receptor genes nor the utilization of tissue-specific transcriptional initiation sites.

Fournal of Molecular Endocrinology (2001) 27, 175-189

\section{INTRODUCTION}

Oxytocin (OT) is a hypothalamic neuropeptide that mediates various reproductive functions. A large body of evidence supports the notion that, as a circulating hormone, this nonapeptide plays a key role in mammals as a mediator of milk ejection from the lactating mammary gland. This has been most convincingly shown by gene ablation studies. Mice in which the OT gene has been inactivated by gene targeting have normal milk production but are unable to deliver the milk to their offspring due to the inability to eject the milk from the glands (Nishimori et al. 1996, Young et al. 1996). Milk ejection is however fully restored in these mice by exogenous OT administration (Nishimori et al. 
1996, Young et al. 1996). In response to the suckling stimulus, OT is released from the neurohypophysis as a result of the synchronous activation of hypothalamic magnocellular OT producing neurons (Belin et al. 1984, Fuchs et al. 1984, Higuchi et al. 1985). Administration of the OT antagonist atosiban inhibits milk ejection and this inhibition is abolished by OT injection (Bruckmaier et al. 1997, Neumann et al. 1994).

OT causes milk ejection by eliciting contractions of the myoepithelial cell network that surrounds the alveoli and milk ducts in the mammary gland (Soloff et al. 1980, Ruberti et al. 1983). In myoepithelial cells, activation of the OT receptor (OTR) was shown to induce intracellular calcium release (Moore et al. 1987). OT was also shown to enhance myoepithelial cell differentiation and proliferation in mammary gland (Sapino et al. 1993). Autoradiographic studies performed in the rat confirmed the presence of OT binding sites on myoepithelial cells (van Leeuwen et al. 1985, Soloff et al. 1975).

Binding studies indicate that uterine and mammary gland OT binding sites are differentially regulated. Uterine binding sites increase dramatically at term, reaching a maximum during labor, and return to baseline during the lactation period. In contrast, mammary gland binding sites undergo a gradual increase throughout gestation and reach a maximum during lactation (Soloff et al. 1979).

The structure of the OTR has been elucidated by molecular cloning in different mammalian species (Kimura et al. 1992, Gorbulev et al. 1993, Bathgate et al. 1995, Riley et al. 1995, Rozen et al. 1995, Kubota et al. 1996). The deduced amino acid sequences indicated that this receptor belongs to the $G$ protein-coupled receptor family. Despite the availability of specific OTR cDNA probes, little is known of the molecular structure and the mechanisms of regulation of mammary gland OTR. Although binding studies suggest a similarity of uterine and mammary gland OTRs, they also indicate that the expression of OTRs is differentially controlled in these two tissues (Soloff et al. 1977, 1979, 1988, Shymala \& Ferenczy 1982, Soloff \& Grzonka 1986, Soloff \& Fernstrom 1987). This notion raises the question whether the tissuespecific regulation is caused by the presence of different OTR subtypes, by differential promoter usage, by different tissue-specific factors interacting at the level of the promoter or by differences in the steroid responsiveness of the OTR-expressing cells in these tissues.

We have previously characterized OTR transcripts in uterus (Larcher et al. 1995), pituitary gland (Breton et al. 1995), kidney (Breton et al. 1996) and brain regions (Breton \& Zingg 1997) and shown that estradiol $\left(\mathrm{E}_{2}\right)$ is a important factor in controlling OTR gene expression. In the present study we have analyzed the molecular structure of the mammary gland and uterine OTR mRNA, determined transcriptional start sites and polyadenylation sites in both tissues, and assessed semiquantitatively mammary gland OTR transcript levels throughout gestation, lactation and in response to gonadal steroid administration.

\section{MATERIALS AND METHODS}

\section{Animals}

Timed-pregnant, lactating or bilaterally ovariectomized Sprague-Dawley female rats (200-250 g) were obtained from Charles River Laboratories (Saint-Constant, Quebec, Canada). Animals were injected on four consecutive days with vehicle (oil), estradiol benzoate $\left(\mathrm{E}_{2}\right)(0.1 \mathrm{mg} / \mathrm{kg})$, progesterone (P) $(10 \mathrm{mg} / \mathrm{kg})$, tamoxifen (TAM) $(10 \mathrm{mg} / \mathrm{kg})$, or a combination of $\mathrm{E}_{2}$ and $\mathrm{P}$ or $\mathrm{E}_{2}$ and TAM. Three hours after the last injection, the animals were killed by decapitation under light ether anesthesia. In ovariectomized animals, treatment was started 1 week after ovariectomy. All procedures were approved by the Bioethics Committee of the Royal Victoria Hospital Research Institute. Tissues were removed, frozen on dry ice and kept at $-70{ }^{\circ} \mathrm{C}$ before RNA extraction.

\section{Northern blot analysis}

Total RNA was extracted from mammary gland or total rat uterus with $4 \mathrm{M}$ guanidinium thiocyanate and purified by ultracentrifugation through $5.7 \mathrm{M}$ $\mathrm{CsCl}$. Total RNA was enriched for polyadenylated RNA by absorption to oligo-d(T) cellulose. Twenty $\mu \mathrm{g}$ of poly(A) ${ }^{+}$mRNA was subjected to electrophoresis in a $1 \%$ agarose $/ 2 \cdot 2 \mathrm{M}$ formaldehyde gel and transferred onto a nylon membrane. The filter was pre-hybridized in $50 \%$ formamide, $5 \times \operatorname{SSPE}(1 \times \mathrm{SSPE}=0.01 \mathrm{M}$ phosphate buffer $(\mathrm{pH}$ $7 \cdot 2$ ) and $0.15 \mathrm{M} \mathrm{NaCl}), 5 \times$ Denhardt's solution, and $100 \mu \mathrm{g} / \mathrm{ml}$ denatured and sheared salmon sperm DNA, and hybridized in the same solution with $3 \times 10^{6}$ d.p.m. $/ \mathrm{ml}$ of random primer labeled cDNA probe at $42{ }^{\circ} \mathrm{C}$ for $16 \mathrm{~h}$. The probe consisted of a $257 \mathrm{bp}$ fragment encoding the N-terminal part of the rat OTR (residues 1-85) (Breton et al. 1995). Washing was performed stepwise in $5 \times \mathrm{SSPE}, 0 \cdot 1 \%$ SDS, $2 \times \mathrm{SSPE}, 0 \cdot 1 \% \mathrm{SDS}$ and $1 \times \mathrm{SSPE}, 0 \cdot 1 \% \mathrm{SDS}$ at $55^{\circ} \mathrm{C}$. Membranes were then exposed at $-70{ }^{\circ} \mathrm{C}$ with intensifying screens for 1-6 days. 


\section{In situ hybridization}

Mammary glands of female rats at day 21 of pregnancy were rapidly dissected out and frozen in dry ice-cooled isopentane and stored at $-20{ }^{\circ} \mathrm{C}$ until sectioning. Adjacent $20 \mu \mathrm{m}$ thick sections were cut on a cryostat, thaw-mounted on gelatincoated slides and stored at $-80{ }^{\circ} \mathrm{C}$. Sense and antisense riboprobes were synthesized using ${ }^{35} \mathrm{~S}$ radiolabeled-UTP and a partial rat OTR cDNA subcloned into pGEM-7Zf+ (provided by Dr P. Burbach, Utrecht; Adan et al. 1995). The frozen sections were thawed and air-dried before fixation in $4 \%$ paraformaldehyde in $0.1 \mathrm{M}$ phosphate buffer for $5 \mathrm{~min}$ at room temperature. After washing in PBS, sections were permeabilized with proteinase $\mathrm{K}(10 \mu \mathrm{g} / \mathrm{ml})$ for $10 \mathrm{~min}$, then postfixed in $4 \%$ paraformaldehyde in $0 \cdot 1 \mathrm{M}$ phosphate buffer for $5 \mathrm{~min}$, treated with acetic anhydride for $10 \mathrm{~min}$, rinsed, dehydrated and delipidated in a series of graded ethanol solutions followed by immersion in chloroform for $5 \mathrm{~min}$. Sections were covered with either sense or antisense probes $(30000$ c.p.m./ $/ \mu \mathrm{l})$ in hybridization buffer and kept for $22 \mathrm{~h}$ in a humid chamber at $56{ }^{\circ} \mathrm{C}$. Sections were washed four times for $5 \mathrm{~min}$ in saline-sodium citrate buffer (SSC) and incubated in a $20 \mu \mathrm{g} / \mathrm{ml} \mathrm{RNase}$ solution at $37^{\circ} \mathrm{C}$ for $30 \mathrm{~min}$, followed by a series of washes in decreasing concentrations of SSC $(4 \times, 2 \times, 1 \times, 0.5 \times \mathrm{SSC}$ for $5 \mathrm{~min}$ each, twice in $0 \cdot 1 \times \mathrm{SSC}$ at $65^{\circ} \mathrm{C}$ for $30 \mathrm{~min}$ ). Sections were dehydrated in graded alcohol solutions containing $300 \mathrm{mM}$ ammonium acetate and $1 \mathrm{mM}$ dithiothreitol (DTT), dried and coated with $\mathrm{K}_{5}$ emulsion (Ilford). After 35 days exposure at $4{ }^{\circ} \mathrm{C}$, the slides were developed for 5 min in Kodak D19 at $18{ }^{\circ} \mathrm{C}$, stained with thionin and mounted with Permount.

\section{RT-PCR}

For the coding region analysis of mammary gland OTR mRNA, two different primer pairs (F3/R8 and F1C/R9) were used as previously described (Breton et al. 1995). The first pair was designed to amplify a $1103 \mathrm{bp}$ cDNA fragment encompassing the coding region of the rat OTR. The second pair amplified a $373 \mathrm{bp}$ region of the coding region, which encompasses the splice site of intron 2.

For the analysis of the $5^{\prime}$ untranslated region, three different primer pairs were used. The common forward primer (F1) consisted of a 24-mer corresponding to nucleotides 1612-1635 and the reverse primers R1 (30-mer), R2 (30-mer) and R3 (27-mer) were complementary to nucleotides 1710$1739, \quad 1910-1949$ and 2095-2121 respectively, according to the published gene sequence (Rozen et al. 1995).

The semi-quantitative RT-PCR method used here has been described and validated earlier (Breton et al. 1995). Briefly, $2 \mu \mathrm{g}$ of total RNA were used for cDNA synthesis with 200 U M-MLV (Moloney murine leukaemia virus) reverse transcriptase, primed with $2 \mu \mathrm{g}$ of random primers in $20 \mu l 50 \mathrm{mM} \mathrm{KCl}(\mathrm{pH} 8 \cdot 3), 50 \mathrm{mM}$ Tris $\mathrm{HCl}(\mathrm{pH}$ 8.3), $10 \mathrm{mM} \mathrm{MgCl}_{2}, 2 \mathrm{mM}$ of each dNTP and $20 \mathrm{U}$ RNasin. The reaction mix was incubated for $1 \mathrm{~h}$ at $42{ }^{\circ} \mathrm{C}$. Negative controls were performed for the first strand synthesis that contained the above reagents but either no RNA or no reverse transcriptase. One-sixth of the first strand synthesis reaction or negative control were then amplified for 35 cycles for OTR cDNA and 25 cycles for glyceraldehyde-3-phosphate dehydrogenase (GAPDH) cDNA. After amplification, the samples were separated on a $1 \%$ agarose gel and transferred to nylon membrane. The blots were hybridized to a radiolabeled oligonucleotide probe that corresponded to the region encoding residues 316-322 of the rat OTR or to residues 157-164 of rat GAPDH. The resulting autoradiograms were scanned densitometrically.

\section{Primer extension}

To determine the initiation sites of OTR gene transcription in uterus and mammary gland, two different primers were used. We found earlier that the main transcriptional initiation site of uterine OTR gene expression was around position 1593 according to the numbering of Rozen et al. (1995). The primers R4 (30-mer) and R5 (30-mer) were complementary to nucleotides 1618-1647 and 1648-1677 respectively (according to Rozen et al. 1995). The antisense primer was labeled at its $5^{\prime}$ end using $\left[{ }^{32} \mathrm{P}\right] \gamma \mathrm{ATP}$ and $\mathrm{T} 4$ polynucleotide kinase. The radiolabeled primer was annealed to $1 \mu \mathrm{g}$ of poly(A)+ enriched RNA and subsequently extended with $200 \mathrm{U}$ M-MLV reverse transcriptase for $30 \mathrm{~min}$ at $37^{\circ} \mathrm{C}$. The extension products were analyzed on a $6 \%$ sequencing gel. The sequencing ladder was obtained using the same oligonucleotide as a primer in a dideoxy sequencing reaction of the corresponding OTR genomic DNA.

\section{Rapid Amplification of cDNA Ends (RACE)}

For both tissues, $3^{\prime}$-rapid amplification of cDNAs ends (RACE) was performed using the SMART RACE cDNA Amplification Kit (Clontech, Palo Alto, CA, USA) as described by the manufacturer. Briefly, first-strand cDNA was synthesized using 
$5 \mu \mathrm{g}$ total RNA, extracted either from rat lactating mammary gland or parturient rat uterus, $200 \mathrm{U}$ M-MLV RT and $10 \mathrm{pmol}$ of a poly(dT) primer adapter $\left(3^{\prime} \mathrm{CDS}\right)$. The cDNAs were amplified in two rounds of 25 cycles each. In the first round, two gene-specific outer primers were used which corresponded to sequence regions located upstream of potential polyadenylylation sites (primer 481: CATTTGTGTGATGCCCAGTGTCC and primer 671: TGGTGGATCTCTGTGAGTTC CAG, corresponding to nucleotides 7030-7052 and 8943-8965 of the published rat OTR sequence respectively (Rozen et al. 1995)). In the second round, the corresponding cDNA generated in the first round of PCR amplification were used as templates, in conjunction with two gene-specific inner primers (primer 482: CAGCTGCTTGATA AATGGTGCAC and primer 672: AGGACA GCCAGGGCTCTGTTACA, corresponding to nucleotides 7089-7111 and 9022-9044 of the published OTR sequence respectively). In both rounds, the unique $3^{\prime}$ primer consisted of a sequence complementary to a portion of the $5^{\prime}$ end of the poly $(\mathrm{d} T)$ primer adapter used for first strand synthesis. The cycling parameters were: $94{ }^{\circ} \mathrm{C}$ for $30 \mathrm{~s}, 60{ }^{\circ} \mathrm{C}$ for $30 \mathrm{~s}$ and $72{ }^{\circ} \mathrm{C}$ for $180 \mathrm{~s}$. PCR products were separated on a $2 \%$ agarose gel, visualized by ethidium bromide staining and photographed under u.v. light. DNA markers were run in parallel to estimate the size of the amplified products. After purification, the PCR products resulting from the second round of PCR amplification were subcloned using the 'pGEM-T Easy Vector Systems' (Promega, Madison, WI, USA) and sequenced on both strands.

\section{DNA sequencing}

The subcloned PCR products were sequenced on both strands using an automated DNA sequencer (ABI PRISM 377 DNA Sequencer, Applied Biosystems, Foster City, CA, USA) and the ABI PRISM Original dRhodamine Terminator Cycle Sequencing Kit (Applied Biosystems). In each reaction, $0.8 \mu \mathrm{g}$ double-stranded DNA was used in conjunction with $\mathrm{pUC} / \mathrm{M} 13$ forward and reverse primers (Promega) and rat OTR gene-specific oligonucleotide primers. The novel $3^{\prime}$ sequence presented here (nucleotides 5872-6489) was derived from two different clones, each sequenced twice in the forward and twice in the reverse direction (using two different forward and two different reverse primers) resulting in a full eightfold sequence coverage. Sequence alignment revealed an average of $3 \cdot 3$ mismatches per raw sequence obtained within the 618 nucleotides of new sequence analyzed. In

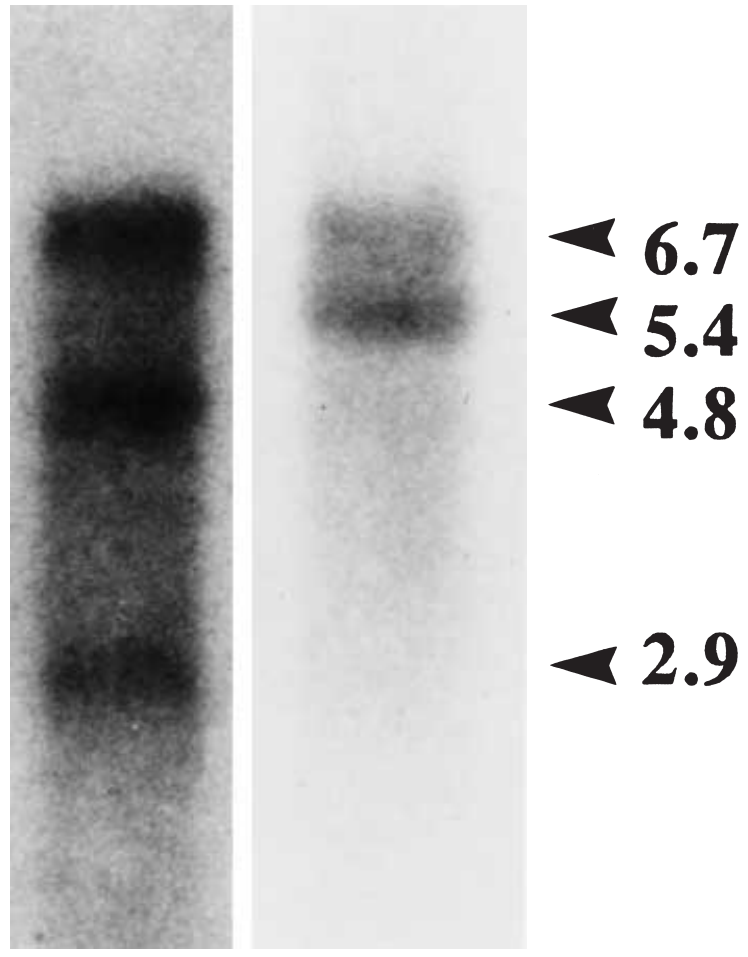

\section{Uterus Mammary gland}

FIGURE 1. Northern blot analysis of mammary gland and uterine OTR mRNA; $20 \mu \mathrm{g}$ of poly(A)-enriched RNA from a parturient rat uterus (left lane) or lactating mammary gland (right lane) were analyzed on a $1 \%$ agarose gel. The blot was probed with a specific rat OTR cDNA probe. Size estimates based on RNA size markers are indicated on the right. Exposure time: $16 \mathrm{~h}$.

each case, the mismatch was confined to one out of the eight sequences and was therefore considered to be a sequencing error.

\section{RESULTS}

\section{Northern blot analysis}

Mammary gland OTR mRNA was characterized by Northern blotting. As shown in Fig. 1, the mammary gland expresses two mRNA species that hybridize to a rat OTR cDNA probe. They were estimated at 6.7 and $5.4 \mathrm{~kb}$. We have shown earlier that the rat uterus contains three different OTR mRNA species that correspond in size to $6 \cdot 7,4 \cdot 8$ and $2.9 \mathrm{~kb}$ and that differ with respect to the length of their $3^{\prime}$ untranslated regions due to differential selection of polyadenylation sites (Rozen et al. 


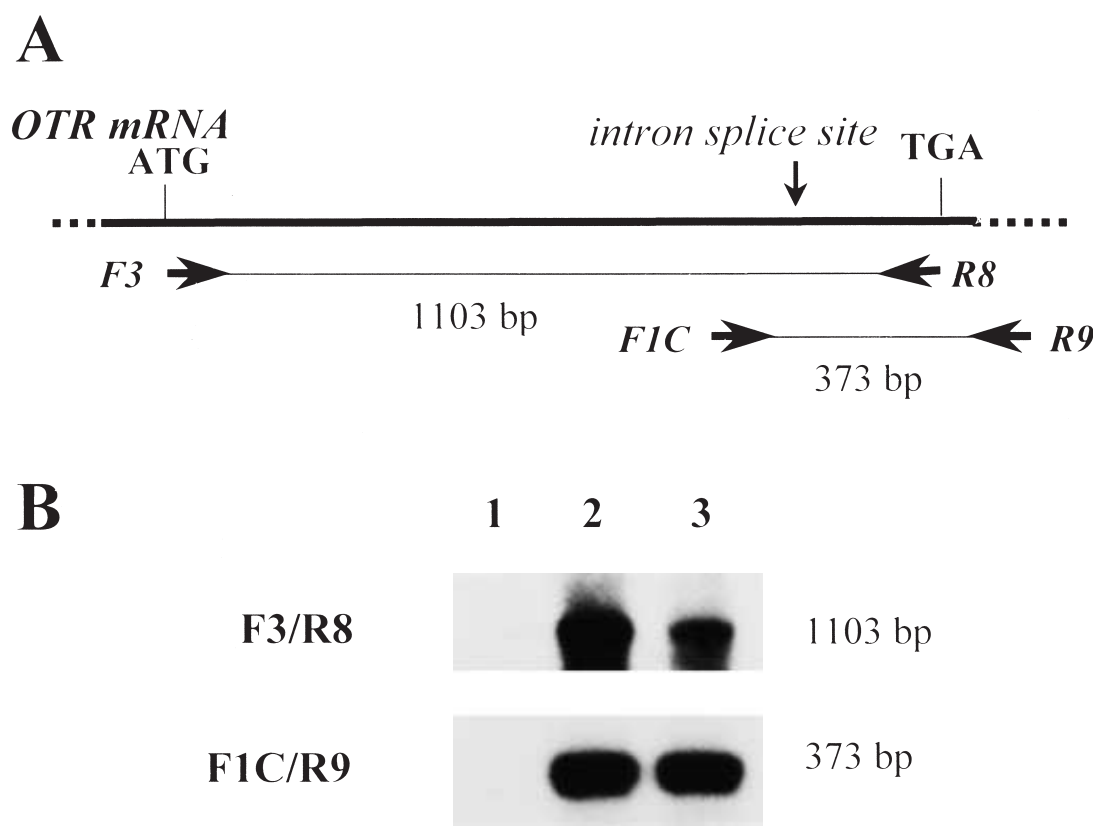

Control Uterus Mammary gland

FIGURE 2. RT-PCR analysis of the coding regions of the mammary gland and uterine OTR mRNA. (A) Schematic diagram of the primers used. The translational initiator codon (ATG), the splice site of a>12 kb intron, and the translational stop codon (TGA) are indicated. (B) RT-PCR amplification of uterine and mammary gland OTR mRNA. RT-PCR was performed using either no RNA (control, lane 1), $3 \mu \mathrm{g}$ of uterine RNA (lane 2), or $3 \mu \mathrm{g}$ of mammary gland RNA (lane 3). PCR amplification was performed using either the F3/R8 or F1C/R9 primer pair, as indicated. PCR amplification products were separated by agarose gel electrophoresis, blotted onto a nylon membrane and hybridized to a labeled, internal, 20-mer oligonucleotide probe.

1995). Thus, the larger transcript identified here in mammary gland is identical in size to the largest OTR transcript present in uterus. As shown earlier, this transcript is also expressed in many other OTR-expressing tissues, including the pituitary gland (Breton et al. 1995), the kidney (Breton et al. 1996) and the brain (Breton \& Zingg 1997). The lower $5.4 \mathrm{~kb}$ band present in mammary gland is not detected in any others tissues expressing OTR mRNA. It is therefore mammary gland-specific.

\section{RT-PCR}

The structure of mammary gland OTR mRNA was further analyzed by RT-PCR. It is known from the analysis of the rat OTR gene that the OTR coding region is interrupted by one large intron (intron 2) located in the region encoding the putative third extracellular domain of the receptor (Rozen et al. 1995). Two sets of primers were used to investigate the coding region (Fig. 2A). The primer pair F3/R8 amplified the coding region encompassing the intron 2 splice site and, in the uterus, gave rise to a $1 \cdot 1 \mathrm{~kb}$ band (Fig. 2B), in accordance with the known

www.endocrinology.org gene structure (Rozen et al. 1995). The F1C/R9 pair amplified a sub-region of the coding region, centered around the intron 2 splice site, resulting, in the uterus, in a $373 \mathrm{bp}$ band. As shown in Fig. 2B, RT-PCR products generated by either set of primers yielded a single band of the predicted size, independent of whether uterus or mammary gland was used as a template. In both cases, the PCR Southern blot (Fig. 2B) and the ethidium bromide stained gels (not shown) exhibited no additional bands that could be indicative of the existence of any splicing variants. These data therefore do not provide any evidence for structural variations, such as alternative splicing of intron 2. The data are thus consistent with the idea that the rat mammary gland and rat uterine OTR transcripts encode the same receptor.

We next analyzed the $5^{\prime}$ untranslated region of uterine and mammary gland OTR mRNA. To this end, RT-PCR experiments were performed with three different sets of primers distributed along this region (Fig. 3A). Based on the reported gene structure (Rozen et al. 1995), application of primer pairs $F 1 / R 3$ and $F 1 / R 2$ were predicted to result 

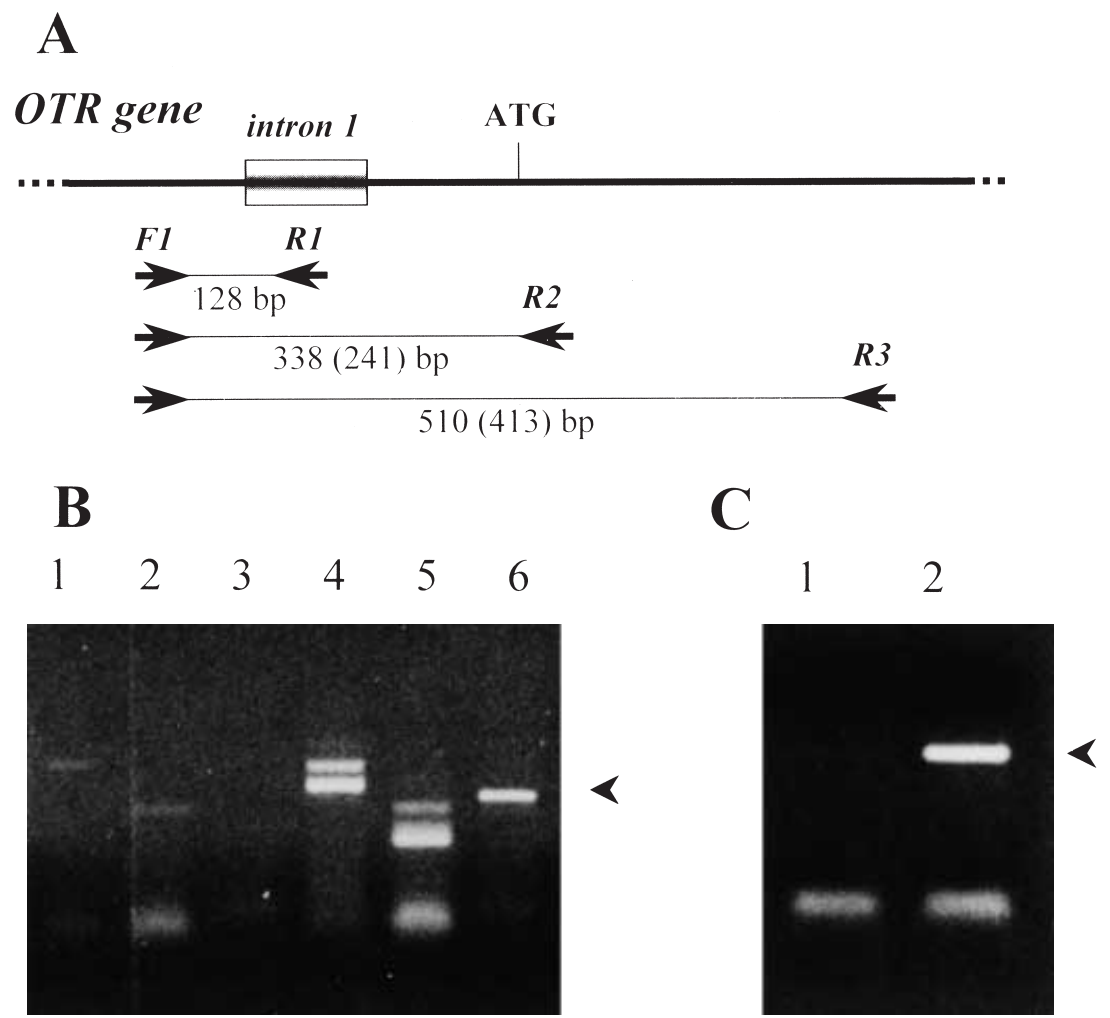

FIGURE 3. RT-PCR analysis of the 5' untranslated region of the mammary gland OTR mRNA. (A) Schematic representation of the $5^{\prime}$ untranslated region and the positions of the oligonucleotide primers used. The $97 \mathrm{bp}$ intron in the 5' untranslated region and the translational initiation codon (ATG) are indicated. (B) and (C) RT-PCR reactions using $3 \mu \mathrm{g}$ of mammary gland RNA for each reaction. Lanes 1-3 (panel B) and lane 1 (panel C) represent control reactions in which no reverse transcriptase was added. In (B), aliquots of the cDNA obtained by reverse transcription of mammary gland mRNA were amplified by PCR using primer pairs F1/R3 (lanes 1 and 4) and F1/R2 (lanes 2 and 5). A 373 bp reaction product obtained with the primer pair F1C/R9 (see Fig. 2) has also been included as a size marker (lane 6, arrowhead). In (C), the cDNA was amplified using primer pair F1/R1 (lanes 1 and 2). The specific amplification product is indicated by arrowhead. The PCR products were separated by agarose gel electrophoresis, stained with ethidium bromide and visualized by u.v. illumination.

in amplification products of $413 \mathrm{bp}$ and $241 \mathrm{bp}$ respectively if intron 1 was spliced out, and of $510 \mathrm{bp}$ and $338 \mathrm{bp}$ respectively if intron 1 was not spliced out. As shown in Fig. 3B, both primer pairs yielded each two bands that were consistent with the presence of two different OTR mRNA types, one containing intron 1 and one in which intron 1 was removed by splicing. The use of a third primer pair, F1/R1, designed to amplify only mRNA containing intron 1, confirmed the presence of mRNA containing intron 1 (Fig. 3C). This situation is analogous to the one described earlier in the uterus (Rozen et al. 1995), where intron 1 is not consistently spliced out, and a portion of OTR mRNA retains the small $97 \mathrm{bp}$ intron. The present observation indicates that the same pertains to mammary gland OTR mRNA. The significance of this observation is unclear, at present. However, the presence of a small open reading frame in intron 1 suggests that presence or absence of intron 1 may have an effect on the translational efficiency of the resulting mRNA (Rozen et al. 1995).

\section{Determination of transcriptional initiation sites by primer extension analysis}

We next examined and compared the transcriptional initiation sites of uterine and mammary gland OTR mRNA. Primer extension revealed several extension products that identified two major transcriptional initiation sites situated at $326 \mathrm{bp}$ and $318 \mathrm{bp}$ upstream from the translational start codon (Fig. 4). Identical primer extension products were obtained using RNA from either uterus or 


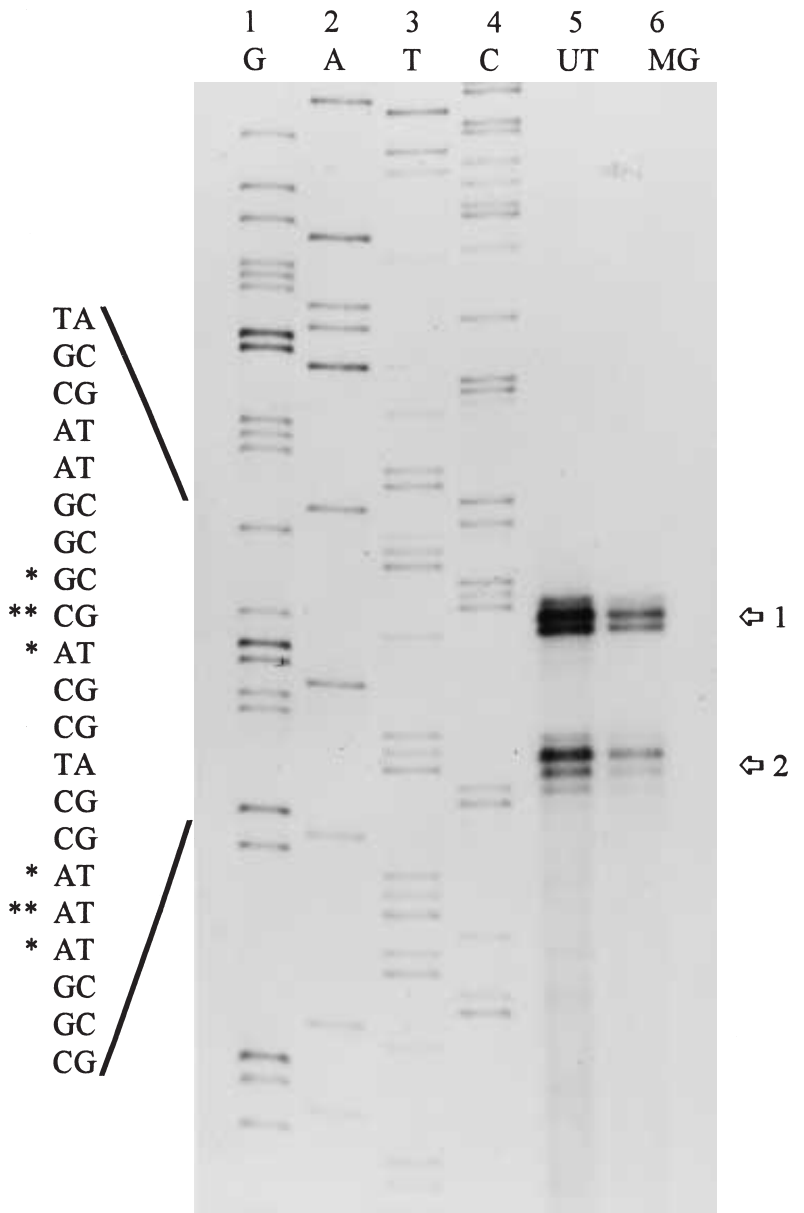

FIGURE 4. Determination of transcriptional start sites of OTR mRNA in uterus and mammary gland by primer extension analysis. Extension products were analyzed on a denaturing polyacrylamide gel. The same primer (R5) was used for dideoxy sequencing reactions (lanes 1-4) and for the primer extension reactions (lanes 5-6). This primer was complementary to nucleotides -273 to -244 relative to the initiation site of translation. A genomic fragment was used as a template for the sequencing reaction. mRNA extracted from a rat uterus at parturition (lane 5) or a lactating rat mammary gland (lane 6) was used for the primer extension reactions. The nucleotide sequence indicated on the left corresponds to nucleotides -334 to -314 relative to the translational initiation codon. The two main initiation sites of transcription are indicated by double asterisks on the left and correspond to the main extension products indicated by the two arrows on the right. Additional, minor initiation sites are indicated by single asterisks. The data shown are representative of three independent experiments that gave identical results.

mammary gland. No products were obtained when RNA extracted from liver was used, a tissue that does not express the OTR gene (data not shown).
These finding indicate that OTR gene transcription initiates in mammary gland at the same site as in the uterus.

\section{Analysis of the $3^{\prime}$ ends by RACE}

The RACE technique was used to further characterize the $3^{\prime}$ end of OTR mRNA detected in mammary gland. As depicted schematically in Fig. $5 \mathrm{~A}$, four different sense primers were used in combination with a common reverse primer that hybridized to the different poly(A) tails. Use of the two upstream primers resulted in each case in three bands of $\sim 1 \cdot 0,0 \cdot 20$ and $0 \cdot 16 \mathrm{~kb}$ respectively (Fig. $5 \mathrm{~B}$, lanes $2-5)$. Whereas the two lower bands were generated irrespective of whether uterine or mammary gland RNA was used as a starting material, the $1.0 \mathrm{~kb}$ band was only generated if RNA extracted from mammary gland was used (lanes 3 and 5 in Fig. 5B). This band, therefore, was indicative of a mammary gland-specific OTR mRNA species. Sequencing of each of these bands determined the sites of polyadenylation in the corresponding template RNA molecules. The deduced sites of polyadenylation are indicated in Fig. 6. Taking into account the transcriptional starting sites determined above and the removal of introns 1 , the predicted sizes of the corresponding OTR mRNA are (without the poly(A) tail): 4.69, 4.75 and $5.49 \mathrm{~kb}$. The $5.49 \mathrm{~kb}$ mRNA species corresponds to the mammary gland-specific mRNA. This size is compatible with the mammary gland-specific band observed by Northern blotting that was estimated at $5.4 \mathrm{~kb}$, as shown in Fig. 1. Of note is that the mammary gland-specific polyadenylation site is not preceded by a classical AAATAAA polyadenylation signal. Thus it remains to be determined what signals the tissue-specific polyadenylation in this particular tissue.

The other two predicted mRNA species correspond to the $4.8 \mathrm{~kb}$ band observed by Northern blotting of uterine-derived RNA. Due to the small size difference of these two mRNAs, they appear as one band in the Northern blot. The detection by RT-PCR of a band corresponding to the $4.8 \mathrm{~kb}$ species in mammary gland extracts was surprising, inasmuch as a corresponding band is only detected in Northern blots of uterine extracts. This is likely due to the greater sensitivity of the RT-PCR technique compared with the Northern blot technique. The fact that, in mammary gland, this species is below the detection limit of the Northern blot approach indicates that it must correspond to a very minor component of mammary gland OTR mRNA.

Using the two primers 671 and 672 that corresponded to regions further downstream on the 

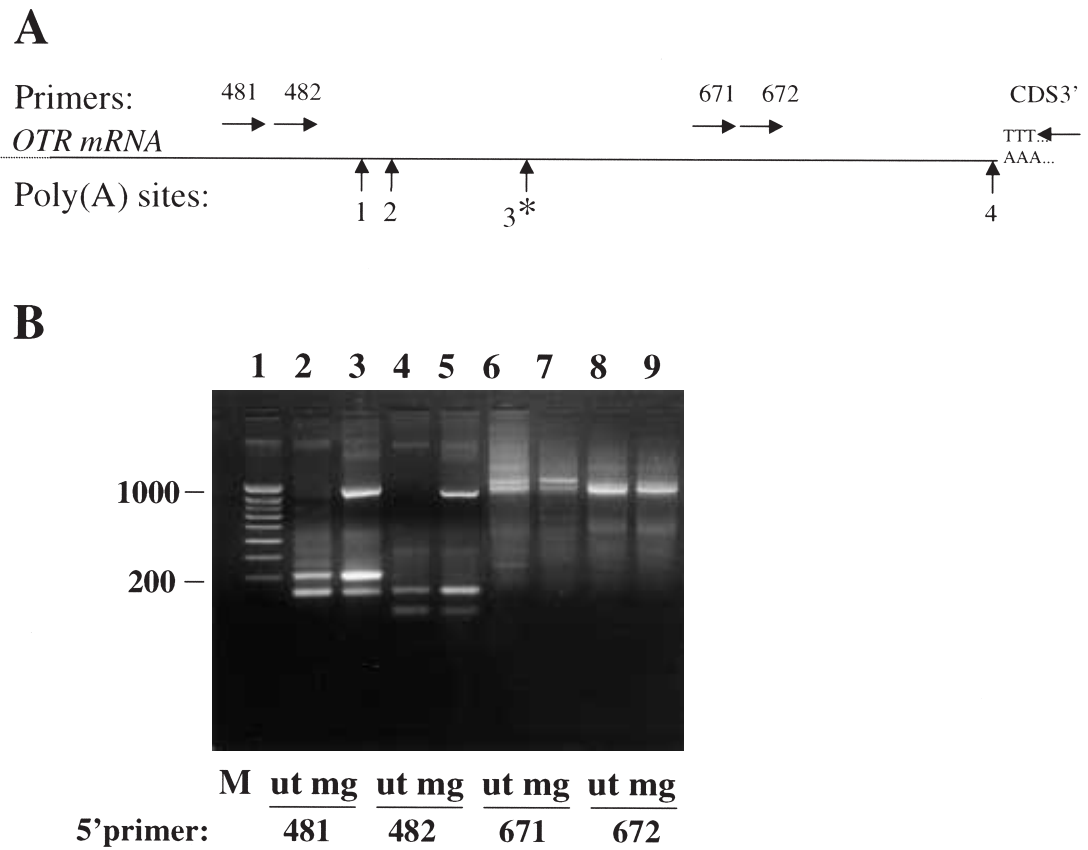

FIGURE 5. Determination of polyadenylation sites of rat mammary gland and uterine OTR mRNA by RACE. (A) Schematic diagram of strategy. A first round of PCR amplification was done using primers 481 and 671 as forward primers and CDS3' as the common reverse primer. The PCR products were used for a second round of amplification using primers 482 and 672 as forward primers and CDS3' as the common reverse primer. The deduced polyadenylation sites are indicated by upward arrows. The mammary gland-specific site is marked by an asterisk. (B) Agarose gel analysis of RACE products. Lane 1: DNA size markers. Target mRNA was extracted from either the uterus of a parturient rat (lanes $2,4,6,8$ ) or a lactating mammary gland (lanes 3, 5, 7, 9). The forward primers used were primer 481 (lanes 2 and 3), 482 (lanes 4 and 5), 671 (lanes 6 and 7), and 672 (lanes 8 and 9). Bands present in lanes $2-5,8$ and 9 were excised from the gel, subcloned and sequenced (see Fig. 6).

OTR mRNA, a band of $\sim 1 \cdot 0 \mathrm{~kb}$ was generated, irrespective of whether uterine or mammary gland RNA was used as a starting material. This size was compatible with the idea that this band corresponded to the $6.7 \mathrm{~kb}$ mRNA species that was common to uterus and mammary gland. The length of the band also suggested that the corresponding polyadenylation occurred at a site that was located over $0.5 \mathrm{~kb} \mathrm{3}$ to the end of the published OTR gene sequence. Sequencing of these bands confirmed this prediction and generated novel sequence information that extends 618 nucleotides beyond the previously published rat OTR gene sequence (Fig. 6). The predicted polyadenylation site is preceded by a classical polyadenylation signal (AAATAAA) located 20 nucleotides upstream of the poly(A) site (Fig. 6, novel sequence is in capitals). The novel 3' sequence contains one $\mathrm{A}$ - and $\mathrm{U}$-rich sequence element that is in addition to the five other elements located further upstream in the previously characterized $3^{\prime}$ untranslated sequence and may play a role in the regulation of mRNA stability. With the added sequence, the length of the $3^{\prime}$ untranslated sequence of the longest OTR mRNA has now been determined to be a total of 6132 nucleotides.

\section{In situ hybridization analysis}

The sites of OTR gene expression in mammary gland were analyzed by in situ hybridization, using a specific antisense ${ }^{35} \mathrm{~S}$-labeled cRNA probe. As shown in Fig. 7a, silver grains were found predominantly in an area located outside, but adjacent to, the epithelial layers of milk ducts. This location is compatible with expression in the myoepithelial cell network that surrounds the mammary gland milk ducts. Only background labeling was observed when a similarly labeled sense strand RNA was used as a probe (Fig. 7b).

\section{Regulation during lactation}

By semi-quantitative Northern blot analysis, we found a non-significant relative $1 \cdot 14$-fold increase of mammary gland OTR mRNA during lactation. However, estimation of mammary gland OTR 
$------p r i m e r \quad 481----\rightarrow$

3550 catttgtgtgatgcccagtgtcccctgcatctggtgagtgacacagcctcctgctttacc ----- primer $482--\rightarrow \quad \downarrow$ poly $(A)$ site 1 3610 agctgcttgataaatggtgcacttaataaacgttctttctgtatatttcattgccttt

\ $\downarrow$ poly (A) site 2 3670 tcctccccgcaaccccgacacccaagaagaatggcatcttatattagcttcctggcaggc 3730 tctgggctcatcttctcgtgatgacacgtgcatgggcttggcaggggcagaggggacctg 3790 gtattattctctggagtcctaggtgtgctcattggtttgtggaaaaatgcaaggatcttg 3850 agccaaagtgtgctgtggtctagatggaaatgtggaatcgttcagtgtaaccttgaaggg 3910 accaggttcccaagcgggaatgtggggaaagcagtccgagcactgggttgctgaggtgtg 3970 gtgtgtttccgctctggggtgggatggtgtggcaagttcacactgttacttctccttta 4030 cagctaactcagatacacacaccctgggcctctgcattcatggtgtttattacggctggt 4090 ggtgcgcacaagctgcatggaaaggtttagtgtgtttcccgctccgtgtctgagccagag 4150 cgggattcctctggggtctgaagtcggggcccattttcagcagttcccggggatgctcac 4210 ctgccetcagtccacctcagctgcctcagagacagcagaagtcatttggaaacaatttcc 4270 tcatatgggaaaccctatttatgcccagcaaacaagtagaatcctgaaggaaacaaaact 4330 tagttctggttttcaatttgcagaggaccaactgaagtttctgggtttcagaactagaaa 4390 aggacacacaaccaccttacagacacagagcatagtgttccctggtgcagccgaaaccct $\downarrow$ mammary gland-specific poly $(A)$ site
4450 ttattgcagcaccttcictatgctggcagtcaccgcttgctctccctagcatgaggagac 4510 gggctacccctctagaagactggtgttggtttgtgctcttacagtacatgtgatcgcaaa 4570 gccttgtgatagctgcctcttaaggaaccctctgcctcaggcagggtcgctggggatcat 4630 ggtaggctgagcagtttccacactgggctgtcttttccttttggctcccctgcaccatgt 4690 actcccattttgaggtggaactgaggagaatcttaaaagcatgagctcgccagcagccca 4750 tgtggagcagagccatgggtgtacacctggccctattccccctgcceagccttccccaca 4810 gcccagccggctttagccttcccttcgcagcaccaccttaatgttgctgccagacctggc 4870 ccagtgcggcaaagagcgggttgcagaaggtgcggatacacagtgagtagatgtggctga 4930 tgcactggatctcaatcaggtagctcttaatgcagggcaccacggcccagatgtggcaga 4990 aggagatacaggcaaacaggaatccccagagcagggccagtggaacacccagcatgtgta 5050 gacagcaggcggtagcaccagtacttggagacggtgaaagtggtgtagctcaccctccac 5110 acgccatcgaagctgtaagtgccctcgcggtccgcaatcacatcttcaaaatccacctgc 5170 aggagccagaagggaaagattaactcacagcatgcgtgggcttttctagtgtttgcttgc 5230 ttgcctacctgcatcggaaatcctgggggtgagtccagggacatggtttagcagctaaga 
5290 gcacttgtcgctcttgcagaagacctgagtttgcttcttagcatatacagaatggctaca

5350 gcaccccataattccagttccaaggaatctaacatcctcctttgaattccagggttccca

5410 gcattcacagaatgaatatatatttttgggaaacagcacttggaaggcagaggtggtgga -- primer $671--\rightarrow$

5470 tctctgtgagttccaggacagcctggtctacaatgtaagttccaggacagcctggtctac ----- primer $672---\rightarrow$

5530 aatgtaagttccaggacagccagggctctgttacactgataataaacaaacaaacaaata

5590 agcaaacacaaaaacaggaaaagggaagaaactctggtagtgtctgttgagcttcttgat

5650 ggtgtcttgacagggtctaggactgtatccctaatgagtgtccaatatggacaataatat

5710 tttctgccagccetgctgacttgccatgcactgtagctacaaggtactctgaagcctgtt

5770 cagcttcttcattctatgcatgtgttaagaggactcccagaagttgaatagcttgttcaa

5830 tactgcagtgctagagtcacagtgcctgctataatttggatcTGTAATGTTCCTCAAAGG

5890 CCCACATGTTAAAGGCTTGGTTCCCAAACCAGTACTACTGGGAGATGGTGAGATCTTTGA

5950 GGGGTGGGATTTAGAGGGAAGAAGCTAGGGCATTTGAAATGTGCTCTGGAGGGGGATGCT

6010 GAGAAGCCTGGTCTCCCCCATCCTTTGTGCTCCCTGGCCATCAGGAACAGTTTGGCTCTA

6070 CCATGTGGTCCTATTACACTGTTCTTGTCTTACCAAAGGACTGAGAGCAACCATACACCT

6130 CCACACCTGTGAGGTACAAGAAATGTTTTTTTCTTTATACATTGCTTATTTCAGGTGTTT

6190 GTTGTAGAGGTGGAGAGATGACACTGCTAGTGTCCTGGCTAATTGTTAACTTGACACAAG

6250 CTTGAGTCATTTGGGAAGAGGGAAGAGAGGTCCCAGCCCCTTGACGTGGTGCTATCCCTG

6310 GGCAGGTGGTGTAGGGGTGTACATGAAAGCAGACCAAGCAAGCCAGTAAGTAGTGTTCCT

6370 CATGGTCTCTGCTTCAGTTCCTGCCTCTAGGTTCCTGTCTTGCTTGAGTTCCTGTCCTGA

6430 CTTCCATTGGTGGTGAAATATACTTGATCCTTGTAAGATGAAATAAACCCTTTCCCCCCC

6490 AAA...

FIGURE 6. Polyadenylation sites of OTR mRNA in rat mammary gland and uterus and novel, additional 3' sequence. Polyadenylation sites and the novel sequence information was determined by RACE as shown in Fig. 4 and described in Materials and Methods. The forward priming sites corresponding to primers 481, 482, 671, and 672 are indicated as well as the polyadenylation sites, including the mammary gland-specific polyadenylation site. The A- and U-rich elements are italicized and the polyadenylation signals are underlined. The novel sequence that extends beyond the published rat OTR gene sequence is in capitals. The numbering is according to, and in extension of, the previously deposited sequence of exon 3 of the rat OTR gene (GenBank accession number U15280). Nucleotides 5290-5871 of the RNA-derived sequence presented here are identical to the gene-derived sequence deposited earlier under the accession number U15280. The novel additional 3' sequence (nucleotides 5872-6490) have been deposited to GenBank under the accession number AF380129. 

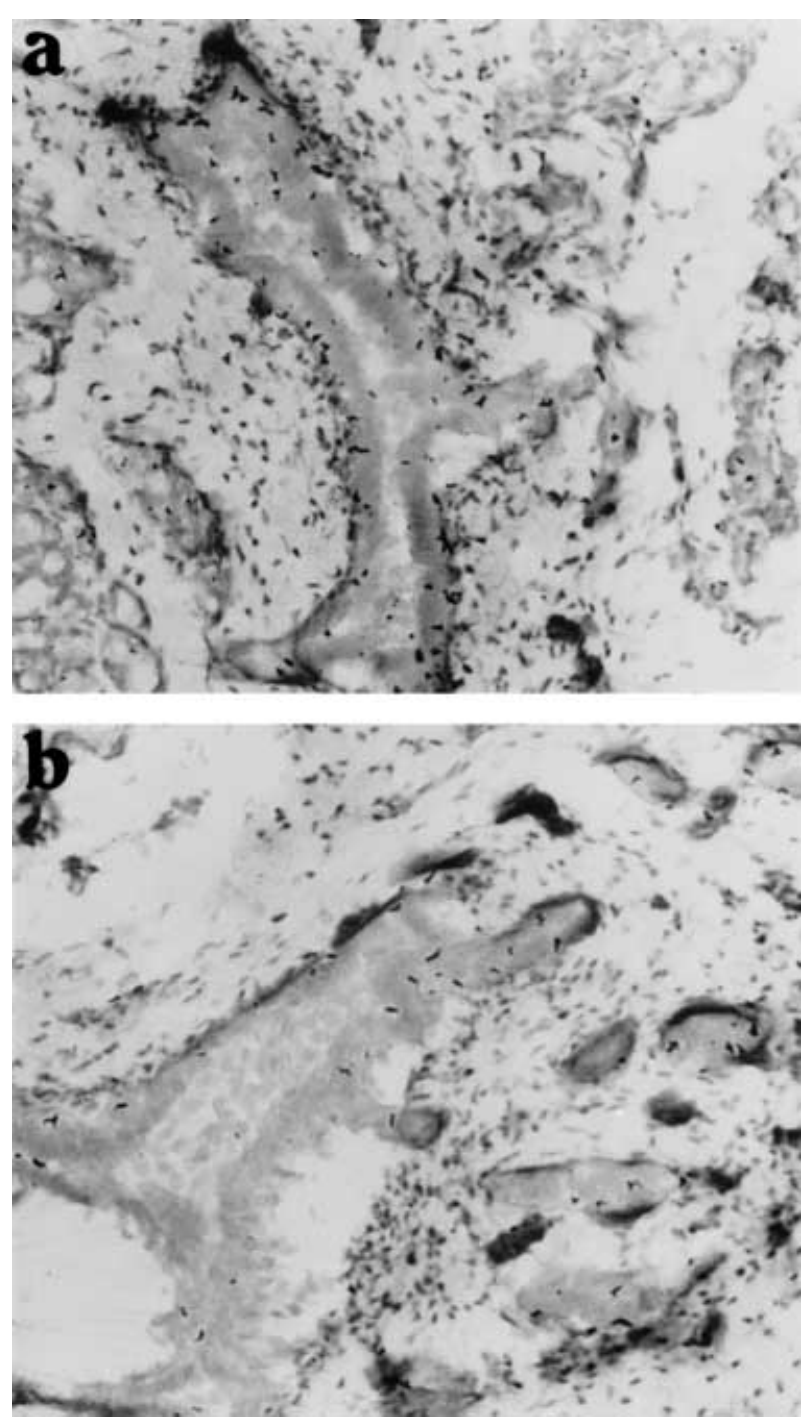

FIGURE 7. Detection of OTR mRNA in rat mammary gland by in situ hybridization analysis. Cryostat sections of 21-day pregnant rat mammary glands were hybridized to an antisense rat OTR-specific ${ }^{35} \mathrm{~S}$-labeled cRNA (a) or to the corresponding sense RNA (b), exposed to a photographic emulsion and viewed under light microscopy. A longitudinally cut mammary gland milk duct is shown in the central part of each panel.

mRNA levels during lactation is complicated by the fact that there is a strong increase in total RNA per mammary gland during this period. During lactation, we found a 13 -fold increase in mammary gland total RNA per mg of tissue. In addition, we found a nearly tenfold increase in rat mammary gland weight (Table 1). Taken together, this indicates that a lactating rat mammary gland contains $\sim 130$ times more RNA than a nonlactating gland, likely due to the strongly increased expression of a set of genes necessary for milk production, secretion and ejection. Since the relative OTR signal remained essentially unchanged as determined by Northern blot analysis, where equal amounts of RNA are loaded per well, we conclude that OTR mRNA per mammary gland increased at approximately at the same rate, i.e. $>100$-fold, and that the OTR gene forms part of the set of genes that is strongly up-regulated during lactation.

\section{Effects of steroids}

We next investigated the effects of in vivo administration of estrogen $\left(\mathrm{E}_{2}\right)$, progesterone $(\mathrm{P})$, or the $\mathrm{E}_{2}$ receptor antagonist tamoxifen (TAM) on OTR mRNA accumulation in the mammary gland. As shown in Fig. 8 and as described earlier (Larcher et al. 1995), the uterine OTR mRNA levels increased in response to $\mathrm{E}_{2}$ administration. By contrast, OTR mRNA levels in the mammary gland remained unaffected by $\mathrm{E}_{2}$ administration (Fig. 8). P administration alone had no significant effect on OTR mRNA levels in both tissues, nor did it significantly influence the $\mathrm{E}_{2}$-induced rise in uterus. In uterus, TAM alone acted as an $\mathrm{E}_{2}$ agonist but weakly suppressed $\mathrm{E}_{2}$-induced OTR gene expression, if administrated concomitantly with $\mathrm{E}_{2}$. By contrast, OTR mRNA levels in the mammary gland remained unaffected by treatment with TAM alone or by combined $\mathrm{E}_{2}$ and TAM administration (Fig. 8).

\section{DISCUSSION}

The present study was prompted by earlier findings demonstrating differential regulation of uterine and mammary gland OT binding sites during pregnancy and lactation (Soloff et al. 1979) as well as in response to steroid treatment (Shyamala \& Ferency 1982). These findings raised the possibility that the OT effects in the mammary gland are mediated by a different OTR subtype. In the present study, we found by Northern blot analysis, RT-PCR and in situ hybridization that the uterine-type OTR mRNA is expressed in mammary gland and that this transcript is regulated in a fashion that is compatible with the observed regulation of OT binding sites, as described in earlier studies (Soloff et al. 1979). Indeed, this conclusion is compatible with earlier binding studies in the literature, which revealed a single class of OT binding sites in mammary gland with characteristics similar to those of uterine binding sites (Soloff et al. 1977, Soloff \& Wieder 1983, Pettibone et al. 1990). Moreover, 
TABLE 1. Semi-quantitative analysis of mammary gland OTR mRNA levels during lactation. Mammary glands of non-pregnant control and day 1 lactating rats were dissected and weighed. Total RNA was extracted and quantitated, and OTR mRNA levels were determined semi-quantitatively by densitometric scanning of autoradiographs resulting from Northern blots such as the one shown in Fig. 1. Values are means \pm s.E.s of four independent determinations. The overall increase in OTR mRNA (149-fold) per mammary gland was calculated taking into account the increase in weight $(9 \cdot 9$-fold), total RNA/mg of tissue $(13 \cdot 1$-fold) and densitometric signal obtained from poly $(\mathrm{A}+)$ RNA purified from $1 \mathrm{mg}$ of total RNA starting material $1 \cdot 14$-fold)

\begin{tabular}{|c|c|c|c|c|}
\hline & $\begin{array}{l}\text { Total weight per } \\
\text { mammary gland }(\mathrm{mg})\end{array}$ & $\begin{array}{l}\text { Total RNA } \\
(\mu \mathrm{g} / \mathrm{mg} \text { tissue })\end{array}$ & $\begin{array}{l}\text { OTR mRNA } \\
\text { (arb. units } / 100 \mu \text { g total RNA) }\end{array}$ & $\begin{array}{l}\text { Calculated increase of OTR } \\
\text { mRNA per mammary gland }\end{array}$ \\
\hline Control & $598 \pm 62$ & $0 \cdot 351 \pm 0 \cdot 021$ & $83 \cdot 8 \pm 10 \cdot 0$ & \\
\hline
\end{tabular}

studies using specific antibodies against the human uterine-type OTR provided evidence of presence of immunologically identical receptor molecules in the human mammary gland (Bussolati et al. 1996, Ito et al. 1996, Sappino et al. 1998). Although the present and previous studies indicate that the uterine-type OTR gene is expressed in mammary gland, the existence of an additional, very different OTR subtype that is sufficiently different to remain unrecognized by the different probes used here cannot be totally excluded.

Our finding of a $6.7 \mathrm{~kb}$ OTR mRNA species that is present in all OTR-expressing tissues examined so far is in support of the idea that the same OTR gene is expressed in all OT-responsive tissues, including the mammary gland. On the other hand, the finding of a $5.4 \mathrm{~kb}$ mammary gland-specific OTR mRNA band raised the possibility that this transcript could originate from differential splicing of the primary OTR transcript or by differential transcriptional initiation of OTR gene transcription. This possibility was further explored using RT$\mathrm{PCR}$ in conjunction with several different sets of primers as well as by primer-extension analysis. Our RT-PCR analysis encompassed a primer pair that flanked the coding region of the OTR gene as well as a pair that amplified specifically a region flanking intron 2 , the single intron that interrupts the OTR coding region. A third pair was designed to amplify the $5^{\prime}$ untranslated region of the OTR mRNA. Neither of these RT-PCR strategies provided evidence for the existence of any differentially spliced OTR transcript with the exception of variable splicing of intron 1 , a small intron present in the $5^{\prime}$ untranslated region. As demonstrated earlier for rat uterine OTR mRNA (Rozen et al. 1995), we found that mammary gland OTR transcripts exist in two forms that differ by the presence or absence of the sequence corresponding to intron 1. The biological significance, if any, of this variable splicing of intron 1 in both tissues
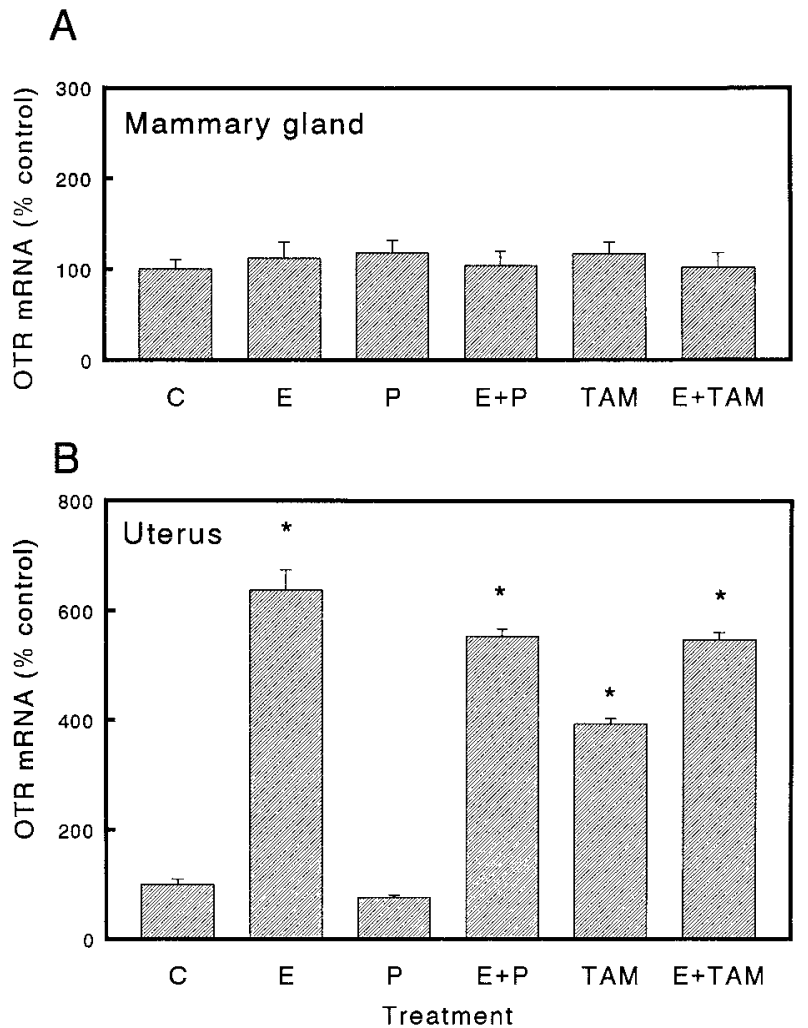

FIGURE 8. Effects of administration of estrogen, progesterone or tamoxifen on OTR mRNA

accumulation in uterus and mammary gland in ovariectomized rats. Animals were injected on four consecutive days with either vehicle (C, control), estradiol benzoate $(\mathrm{E})$, progesterone $(\mathrm{P})$, both estradiol benzoate and progesterone $(\mathrm{E}+\mathrm{P})$, tamoxifen $(\mathrm{TAM})$ or estradiol benzoate and tamoxifen (E+TAM). OTR mRNA were determined semi-quantitatively using an RT-PCR assay described previously (Breton et al. 1995).

Each bar represents the mean \pm S.E. of the results obtained from four different animals, assayed each independently. Means that differ significantly from control $(P<0 \cdot 01)$ are indicated by an asterisk. 
remains unclear. Since an open reading frame consisting of seven codons is present in intron 1, the two types of OTR mRNA may differ with respect to their translational efficiency. Since the two splicing variants only differ by 97 nucleotides, they are not distinguishable by Northern blot analysis.

Differential selection of transcriptional initiation sites represents an alternative mechanisms that could underlie the production of differentially sized mRNAs. Differential transcriptional initiation resulting in differential promoter usage has indeed been found to occur in genes that encode members of the G-protein coupled receptor family and include the PTH/PTHRP receptor gene (McCuaig et al. 1995) and the $\alpha$-adrenergic receptor gene (Gao \& Kunos 1994). The results from our primer extension studies do not support the hypothesis that such a mechanism underlies the tissue-specific differential regulation of the OTR gene, since we found that OTR transcription initiates at exactly the same positions in mammary gland and uterine tissues.

An alternative explanation for the existence of a mammary gland-specific $5.4 \mathrm{~kb}$ OTR mRNA band is differential selection of polyadenylation sites. We have shown earlier that the heterogeneity of uterine OTR mRNA is due to differential selection of polyadenylation sites. Our present data demonstrate that the same applies to OTR gene expression in the mammary gland. In addition, we found that polyadenylation site selection in OTR gene transcripts is also tissue specific, and that the existence of a mammary gland-specific $5 \cdot 4 \mathrm{~kb}$ transcript is due to selection of a distinct, tissue-specific polyadenylation site. The mechanisms and biological significance, if any, of the differential polyadenylation site selection remain to be explored.

Analysis of mammary gland OTR gene expression during pregnancy and lactation demonstrated a distinct pattern that differed from any other tissue in which OTRs are expressed. In kidney, OTR gene expression decreases at term, whereas in certain extra-hypothalamic brain regions, OTR mRNA levels remain constant (Breton et al. 1996, Breton \& Zingg 1997). In uterus, pituitary gland and hypothalamus, there is a strong but short-lasting increase in OTR expression around the time of parturition (Breton et al. 1995, Larcher et al. 1995, Breton \& Zingg 1997). In contrast, OTR levels per mammary gland undergo an increase during the period of lactation. This distinct pattern of OTR gene regulation is compatible with the function that OT assumes during lactation as well as with earlier OT binding studies (Soloff et al. 1979). Based on our in situ hybridization studies, mammary gland
OTR expression is most marked in the milk ducts of the mammary gland and occurs mainly in a layer adjacent to the epithelial cell layer, corresponding to the myoepithelial cell network.

Since the mammary gland is an estrogen-sensitive organ and since we have shown earlier that the OTR is up-regulated in response to estrogens in uterus, kidney, pituitary and hypothalamus (Breton et al. 1995, 1996, Larcher et al. 1995, Breton \& Zingg 1997), the absence of any steroid response of mammary gland OTR expression is surprising. There is abundant evidence that the mammary gland is indeed an estrogen sensitive-organ: estrogen administration promotes mammary gland growth and differentiation in vivo (Dilly \& Nandi 1968, Hoshiai et al. 1982, Klinge et al. 1987), estrogen binding sites have been demonstrated on mammary gland stroma and epithelial cells (Hsuch et al. 1973, Auricchio et al. 1975, Buell \& Tremblay 1984), and transcripts encoding estrogen receptor alpha and beta have been detected in mammary gland (Couse et al. 1997). However, although estrogen administration induces alterations in the myoepithelial cells of the rat mammary gland (Strum 1978), to our knowledge, no direct evidence for the specific presence of estrogen receptors in myoepithelial cells has been provided so far. Although the possible absence of any estrogen receptors from myoepithelial cell remains to be formally excluded, it represents nevertheless an unlikely explanation for the observed results.

A more likely possibility is that the estrogen effect on OTR gene expression is indirect and is either mediated via a paracrine action of an adjacent cell population or, more likely, via the steroid-mediated induction of another gene, expressed in the same cell, that affects OTR gene expression in trans (see Ivell \& Walther 1999 for review). The latter hypothesis is strengthened by the finding that the OTR gene does not contain a classical estrogen response element, and that in transient transfection experiments in human mammary gland tumor cells, the existing non-classical response element remains ineffective at its original position in the promoter (Bale \& Dorsa 1997). Thus the estrogen induction of the OTR gene is most likely mediated via additional trans-acting gene(s), such as, for example, c-fos, which is involved in mediating the estrogen induction of the prolactin gene in pituitary lactotrophs (Allen et al. 1997). Additional tissueand cell-specific factors that remain to be identified may further modulate the site- and stage-specific expression of the OTR gene in different tissues.

In conclusion, the present demonstration of tissue-specific differential regulation of a single OTR gene under the control of a single promoter 
represents an attractive model system for the combinatorial interplay of cell-specific factors that modulate gene expression and allow the hormone OT to assume multiple functions in a physiologically appropriate manner.

\section{ACKNOWLEDGEMENTS}

The present studies were supported by grants from the Canadian Institutes of Health Research (CIHR). CB was supported by a fellowship from the Royal Victoria Hospital Research Institute. HHZ is holder of a CIHR Senior Scientist Award and of a Wyeth-Ayerst Clinical Research Chair in Women's Health. We thank Ms L Monaco for excellent secretarial assistance and Ms S Ruault for technical help.

\section{REFERENCES}

Adan RAH, van Leeuwen FW, Sonnemans MAF, Brouns M, Hoffmann G, Verbalis JG \& Burbach JPH 1995 Rat oxytocin receptor in brain, pituitary, mammary gland and uterus: partial sequence and immunocytochemical localization. Endocrinology 136 4022-4028.

Allen DL, Mitchner NA, Uveges TE, Nephew KP, Khan S \& Ben-Jonathan N 1997 Cell-specific induction of c-fos expression in the pituitary gland by estrogen. Endocrinology 138 2128-2135.

Auricchio F, Rotondi A \& Bresciani F 1975 Oestrogen receptor in mammary gland cytosol of virgin, pregnant and lactating mice. Molecular and Cellular Endocrinology 4 55-60.

Bale TL \& Dorsa DM 1997 Cloning, novel promoter sequence and estrogen regulation of a rat oxytocin receptor gene. Endocrinology 38 1151-1158.

Bathgate R, Rust W, Balvers M, Hartung S, Morley S \& Ivell R 1995 Structure and expression of the bovine oxytocin receptor gene. DNA and Cell Biology 14 1037-1048.

Belin V, Moos F \& Richard P 1984 Synchronization of oxytocin cells in the hypothalamic paraventricular and supraoptic nuclei in suckled rats: direct proof with paired intracellular recordings. Experimental Brain Research $\mathbf{5 7}$ 201-203.

Breton C \& Zingg HH 1997 Expression and region-specific regulation of the oxytocin receptor gene in rat brain. Endocrinology 138 1857-1861.

Breton C, Pechoux C, Morel G \& Zingg HH 1995 Oxytocin receptor messenger ribonucleic acid: characterization, regulation, and cellular localization in the rat pituitary gland. Endocrinology $1362928-2936$.

Breton C, Neculcea J \& Zingg HH 1996 Renal oxytocin receptor messenger ribonucleic acid: characterization and regulation during pregnancy and in response to ovarian steroid treatment. Endocrinology 137 2711-2717.

Bruckmaier RH, Wellnitz O \& Blum JW 1997 Inhibition of milk ejection by oxytocin receptor blockade, alpha-adrenergic receptor stimulation and in unfamiliar surroundings. Fournal of Dairy Research 64 315-325.

Buell RH \& Tremblay G 1984 Autoradiographic demonstration of $\left[{ }^{3} \mathrm{H}\right]$ estradiol incorporation in benign mammary lesions. American Fournal of Clinical Pathology 81 30-34.

Bussolati L, Cassoni P, Ghisolfi G, Negro F \& Sapino A 1996 Immunolocalization and gene expression of oxytocin receptors in carcinomas and non-neoplastic tissues of the breast. American Fournal of Pathology 148 1895-1903.

Couse JF, Lindzey J, Grandien K, Gustafsson JA \& Korach KS 1997 Tissue distribution and quantitative analysis of estrogen receptor-alpha (ER alpha) and estrogen receptorbeta (ER beta) messenger ribonucleic acid in the wild-type and ER alpha-knockout mouse. Endocrinology 138 4613-4621.

Dilly WG \& Nandi S 1968 Rat mammary gland differentiation in vitro in the absence of steroid. Science 161 59-60.

Fuchs AR, Cubile L, Dawood MY \& Jorgensen FS 1984 Release of oxytocin and prolactin by suckling in rabbits throughout lactation. Endocrinology 114 462-469.

Gao B \& Kunos G 1994 Transcription of the rat alpha 1B adrenergic receptor gene in liver is controlled by three promoters. Fournal of Biological Chemistry 269 15762-15767.

Gorbulev V, Büchner H, Akhundova A \& Fahrenholz F 1993 Molecular cloning and functional characterization of V2 (8-lysine) vasopressin and oxytocin receptors from a pig kidney cell line. European Fournal of Biochemistry 215 $1-7$.

Higuchi T, Honda K, Fukuoka T, Negoro H \& Wakabayashi K 1985 Release of oxytocin during suckling and parturition in the rat. Fournal of Endocrinology 105 339-346.

Hoshiai H, Takahashi K, Furuhashi N, Wada Y, Uehara S \& Suzuki M 1982 Cytoplasmic estrogen receptors of rat mammary glands during pregnancy and puerperium. Tohoku Fournal of Experimental Medicine 136 195-202.

Hsuch AJ, Peck EJ Jr \& Clark JH 1973 Estrogen receptor in the mammary gland of the lactating rat. Fournal of Endocrinology 58 503-511.

Ito Y, Kobayashi T, Kimura T, Matsuura N, Wasasugi E, Takeda T, Shimano T, Kubota Y, Nobunaga T, Makino Y, Azuma C, Saji F \& Monden M. 1996 Investigation of the oxytocin receptor expression in human breast cancer tissue using newly established monoclonal antibodies. Endocrinology $137773-779$

Ivell R \& Walther N 1999 The role of sex steroids in the oxytocin hormone system. Molecular and Cellular Endocrinology 151 95-101.

Kimura T, Tanizawa O, Mari K, Browstein MJ \& Okayama H 1992 Structure and expression of a human oxytocin receptor. Nature 356 526-529.

Klinge CM, Bambara RA, Zain S \& Hilf R 1987 Estrogen receptor binding to nuclei from normal and neoplastic rat mammary tissues in vitro. Cancer Research $\mathbf{1 1}$ 2852-2859.

Kubota Y, Kimura T, Hashimoto K, Tokugawa Y, Nobunaga K, Azuma C, Saji F \& Murata Y 1996 Structure and expression of the mouse oxytocin receptor gene. Molecular and Cellular Endocrinology 124 25-32.

Larcher A, Neculcea J, Breton C, Arslan A, Rozen F, Russo C \& Zingg HH 1995 Oxytocin receptor gene expression in the rat uterus during pregnancy and in response to gonadal steroid treatment. Endocrinology 136 5350-5356.

van Leeuwen FW, van Heerikhuize J, van der Meulen G \& Wolters P 1985 Light microscopic autoradiographic localization of $\left[{ }^{3} \mathrm{H}\right]$ oxytocin binding sites in the rat brain, pituitary and mammary gland. Brain Research 359 320-325.

McCuaig KA, Lee HS, Clarke C, Assar H, Horford J \& White JH 1995 Parathyroid hormone/parathyroid related peptide receptor gene transcripts are expressed from tissue-specific and ubiquitous promoter. Nucleic Acid Research 23 1948-1955.

Moore DM, Vogl AW, Baimbridge K \& Emerman JT 1987 Effects of calcium on oxytocin-induced contraction of mammary gland myoepithelium as visualized by NBD-phallaeidin. Fournal of Cell Science 88 563-569. 
Neumann I, Koehler E, Landgraf R \& Summy-long J 1994 An oxytocin receptor antagonist infused into the supraoptic nucleus attenuates intranuclear and peripheral release of oxytocin during suckling in conscious rats. Endocrinology 134 141-147.

Nishimori K, Young LY, Guo Q,Wang Z, Insel TR \& Matzuk M 1996 Oxytocin is required for nursing but is not essential for parturition or reproductive behavior. PNAS 93 11699-11704.

Pettibone DJ, Woyden CJ \& Totaro JA 1990 Identification of functional oxytocin receptors in lactating rat mammary gland in vitro. European Fournal of Pharmacology 188 235-241.

Riley PR, Flint AP, Abayasekara DR \& Stewart HJ 1995 Structure and expression of an ovine endometrial oxytocin receptor cDNA. Fournal of Molecular Endocrinology 15 195-202.

Rozen F, Russo C, Banville D \& Zingg HH 1995 Structure, characterization, and expression of the rat oxytocin receptor gene. PNAS 92 200-204.

Ruberti A, Olins GM, Eakle KA \& Bremel RD 1983 Oxytocin binding by myoepithelial cell membranes from involuted mammary tissue. Biochemical and Biophysical Research Communications 112 717-722.

Sapino A, Macri L, Tonda L \& Bussolati L 1993 Oxytocin enhances myoepithelial cell differentiation and proliferation in the mouse mammary gland. Endocrinology 133 838-842.

Sapino A, Cassoni P, Stella A \& Bussolati L 1998 Oxytocin receptor within the breast: biological function and distribution. Anticancer Research 18 2181-2186.

Shyamala G \& Ferenczy A 1982 The nonresponsiveness of lactating mammary gland to estradiol. Endocrinology 110 1249-1256.

Soloff MS \& Fernstrom MA 1987 Solubilization and properties of oxytocin receptors from rat mammary gland. Endocrinology 120 2474-2482.
Soloff MS \& Grzonka Z 1986 Binding studies with rat myometrial and mammary gland membranes on effects of manganese on relative affinities of receptors for oxytocin analogs. Endocrinology 119 1564-1569.

Soloff MS \& Wieder MH 1983 Oxytocin receptors in rat involuting mammary gland. Canadian Fournal of Biochemistry and Cell Biology 61 631-635.

Soloff MS, Rees HD \& Stumpf WE 1975 Autoradiographic localization of radioactivity from $\left[{ }^{3} \mathrm{H}\right]$ oxytocin in the rat mammary gland and oviduct. Endocrinology 96 1475-1477.

Soloff MS, Schroeder BT, Chakraborty J \& Pearlmutter AF 1977 Characterization of oxytocin receptors in the uterus and mammary gland. Federation Proceedings 36 1861-1866.

Soloff MS, Alexandrova M \& Fernstrom MJ 1979 Oxytocin receptors: triggers for parturition and lactation? Science 204 1313-1315.

Soloff MS, Chakraborty J, Sadhukhan P, Senitzer D, Wieder MH, Fernstrom MA \& Sweet P 1980 Purification and characterization of myoepithelial and secretory cells from the lactating rat. Endocrinology 106 887-897.

Soloff MS, Beauregard G \& Potier M 1988 Determination of the functional sizes of oxytocin receptors in plasma membranes from mammary gland and uterine myometrium of the rat by radiation inactivation. Endocrinology 122 $1769-1772$.

Strum JM 1978 Estrogen-induced alterations in the myoepithelial cells of the rat mammary gland. Cell and Tissue Research 193 155-161.

Young WS, 3rd, Shepard E, Amico J, Hennighausen L, Wagner KU, LaMarca ME, McKinney C \& Ginns EI 1996 Deficiency in mouse oxytocin prevents milk ejection, but not fertility or parturition. Fournal of Neuroendocrinology $\mathbf{8}$ $847-853$.

RECEIVED 11 April 2001

ACCEPTED 30 May 2001 